\title{
Influence of transport activity on environmental factors in Petroşani Basin
}

\author{
Sorin Mihăilescu ${ }^{1 *}$, and Gabriel Praporgescu ${ }^{1}$ \\ ${ }^{1}$ University of Petroşani, Mechanical, Industrial and Transports Engineering Department, 20 \\ Universităţii Street, Petroşani, România
}

\begin{abstract}
Economic development is closely linked to the mobility needs of communities. The main pillars supporting sustainable development are society, the environment and the economy, and the diagnosis of the current situation, the identification of solutions, the development plans and their implementation lead to sustainable development in terms of transport activity. As the Petroşani Basin has a high degree of urbanization, the negative effects of increased road traffic are particularly pronounced in the central areas of the cities. Of the environmental factors, air is the most obvious and most important factor in human health. Taking into account the national and European Community targets in terms of climate change mitigation, the reduction of air and noise pollution and greenhouse gas emissions is becoming a priority objective. Thus, by limiting the growth of road traffic and the adoption of strategic measures in the Petroşani Basin, a reduction in carbon dioxide emissions, nitrogen oxides and particulate matter levels will also be achieved. According to these trends, achieving a clean public transport system and sustainable (like electrical buses) and having infrastructure for the use of electric bicycles and trotters can do for sure reducing the pollutant emissions.
\end{abstract}

\section{Introduction}

Of the environmental factors, air is the most obvious and most important factor in human health. Taking into account the national and European Community objectives in terms of climate change mitigation, the reduction of air and noise pollution and greenhouse gas emissions is becoming a priority objective. According to the European Parliament resolution of 23 April 2009 on the Intelligent Transport Systems Action Plan, road transport accounts for $72 \%$ of all $\mathrm{CO}_{2}$-related transport emissions, while $40 \%$ of the $\mathrm{CO}_{2}$ emissions from road transport in Europe are generated urban traffic [1]. As the Petroşani Basin has a high degree of urbanization (comprising the towns of Petrila - 21,373 inhabitants, Petroşani - 34,331 inhabitants, Aninoasa - 4,225 inhabitants, Vulcan - 22,906 inhabitants, Lupeni 23,390 inhabitants and Uricani - 8,618 inhabitants) the negative effects of increased road traffic are particularly pronounced in the downtown area [2].

\footnotetext{
*Corresponding author: mihailescus@gmail.com, gpraporgescu@gmail.com
} 


\section{About road traffic in Petroșani Basin}

In order to obtain an overview of the possible influence of general road traffic on the air environment factor, a traffic study was carried out. The traffic study was conducted taking into account traffic values over a 24 -hour period, at predetermined intervals at selected points for traffic volume measurements. Taking into account that these points are traffic junctions that attract major traffic flows and are areas with maximum traffic volumes at peak hours, it is obvious that an analysis of their traffic parameters will provide a real picture of the overall road traffic in the Petroşani Basin.

Traffic data obtained were processed in order to get a conclusion on the evolution of traffic volumes during the day. In Figure 1 is shown graphically, for example, the results for the 1 Decembrie 1918 Boulevard and Nicolae Bălcescu Street intersection, located in Petroșani, this being the busiest intersection of the studied area.

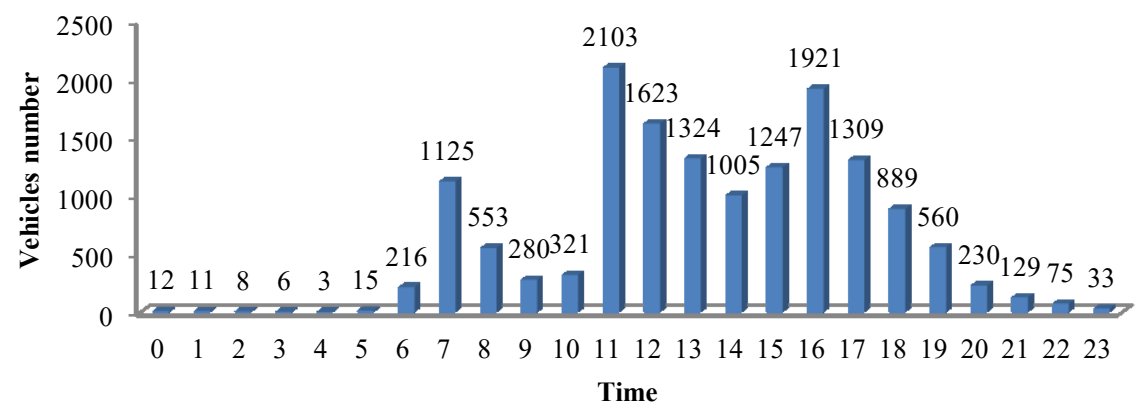

Fig. 1. Traffic volumes for a day at the 1 December 1918 Boulevard - Nicolae Bălcescu Street.

In the example shown in Figure 1, it is noted that at peak times are from 07.00 to 08.00 for morning traffic, 11.00 to 13.00 for midday traffic and 15.00 to 17.00 for afternoon traffic. The peaks correspond to population movements to/from work and start/end of courses students. The peak observed at around 12.00 due to traffic generated by taking pupils from schools.

The traffic study also estimated the current and prospective annual average daily traffic (AADT) (Figure 2) for the period 2015-2040 on the DN66/E79 entry point in Petroșani from Deva, expressed in total vehicles and standard cars.

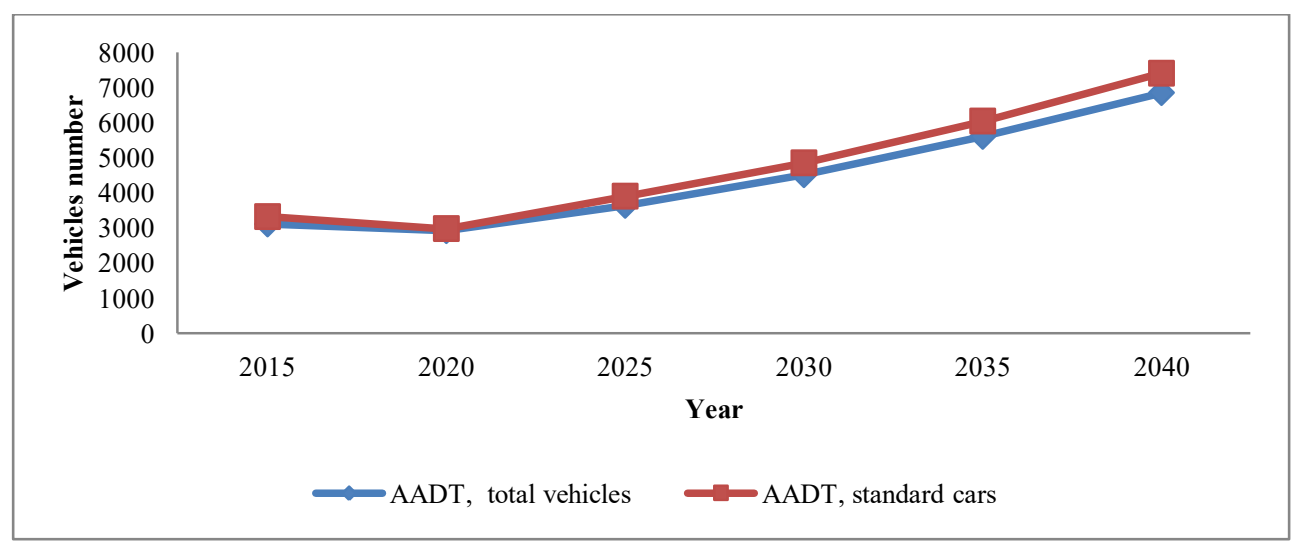

Fig. 2. Estimated traffic for DN66/E79 entry point in Petroșani from Deva. 
The conclusions of the traffic survey are as follows:

- General road traffic does not show major congestion during the day;

- In most time intervals, all vehicles are served by intersections on a single green cycle;

- In peak hours, columns of vehicles are formed, exceeding the capacity of the intersections;

- The average city speed is $30 \mathrm{~km} / \mathrm{h}$.

\section{About air pollution in Petroșani Basin}

Air is the natural environment factor with the most obvious and important implications for human health. In the Petroşani Basin, the main sources of air pollution are the Paroşeni Thermoelectric Power Plant, Lonea, Livezeni, Vulcan and Lupeni mines and the road traffic.

In accordance with the Law no. 104 of 15 June 2011 on ambient air quality, the limit values for the protection of human health of the air quality indicators are:

- $\mathrm{CO}-10 \mathrm{mg} / \mathrm{mc}$ - limit value (maximum daily mean value over 8 hours);

- $\mathrm{SO}_{2}-125 \mu \mathrm{g} / \mathrm{mc}$ - daily limit value;

- $\mathrm{NO}_{\mathrm{X}}-40 \mu \mathrm{g} / \mathrm{m} 2 \mathrm{NO} 2$ - daily limit value;

- $\mathrm{C}_{6} \mathrm{H}_{6}-5 \mu \mathrm{g} / \mathrm{mc}$ - annual limit value;

- PM10 - $50 \mu \mathrm{g} / \mathrm{mc}$ - daily limit value;

- PM10 - $40 \mu \mathrm{g} / \mathrm{mc}$ - annual limit value.

Measurement of air quality in the Petroşani Basin is carried out with a manual industrial monitoring network (the range of the representative area is $100 \mathrm{~m}-1 \mathrm{~km}$ ) (Table 1) and the automatic industrial monitoring station located in Vulcan on Mihai Viteazu Boulevard [3]. Manual air quality monitoring was provided by 3 control points equipped with aerosol suction pumps (suspended particulate matter) and 6 points for sedimentable dust, according to STAS $12574 / 87$

Table 1. Manual Air Quality Monitoring Network in the Petroşani Basin

\begin{tabular}{|c|c|}
\hline Station & Pollution matter \\
\hline $\begin{array}{c}\text { Livezeni, Hydroconstruction } \\
\text { Headquarters }\end{array}$ & Suspended particulate matter \\
\hline Paroșeni, DN66A, Dam & Suspended particulate matter \\
\hline Paroșeni, no. 25, Minei Street & Sedimentable dust \\
\hline Vulcan, no. 14, Decebal Street & Sedimentable dust \\
\hline Lupeni, no. 7, Sohodol Street & Sedimentable dust \\
\hline Petroșani, University & Suspended particulate matter \\
\hline Petroșani, no. 4, 22 Decembrie Street & Sedimentable dust \\
\hline $\begin{array}{c}\text { Livezeni, Hydroconstruction } \\
\text { Headquarters }\end{array}$ & Sedimentable dust \\
\hline Iscroni, Coroești, no. 10, Secului Street & Sedimentable dust \\
\hline
\end{tabular}


The main potential sources of pollution with sedimentable dust and suspended particulate matter are power plants, transports, etc. It mainly mentions tailings dumps and tailings ponds, as a feature of the Petroşani Basin, whose particles are driven by wind over distances of tens of kilometers. Mineral powders contained in the flue gases discharged into the atmosphere, especially when the gas treatment plant malfunctions or is not working at all, represents a serious danger to plant, soil and air. The presence of solid particles in the atmosphere adversely affects the air transparency, favors the air heating by accumulating a part of the solar heat and changes the precipitation regime. Figure 3 shows the variation in monthly averages for air quality indicators (suspended particulate matter, PM10, sedimentable dust) and Figure 4 shows the maximum values of the same indicators, resulting from manual measurements between January 2018 and December 2018.

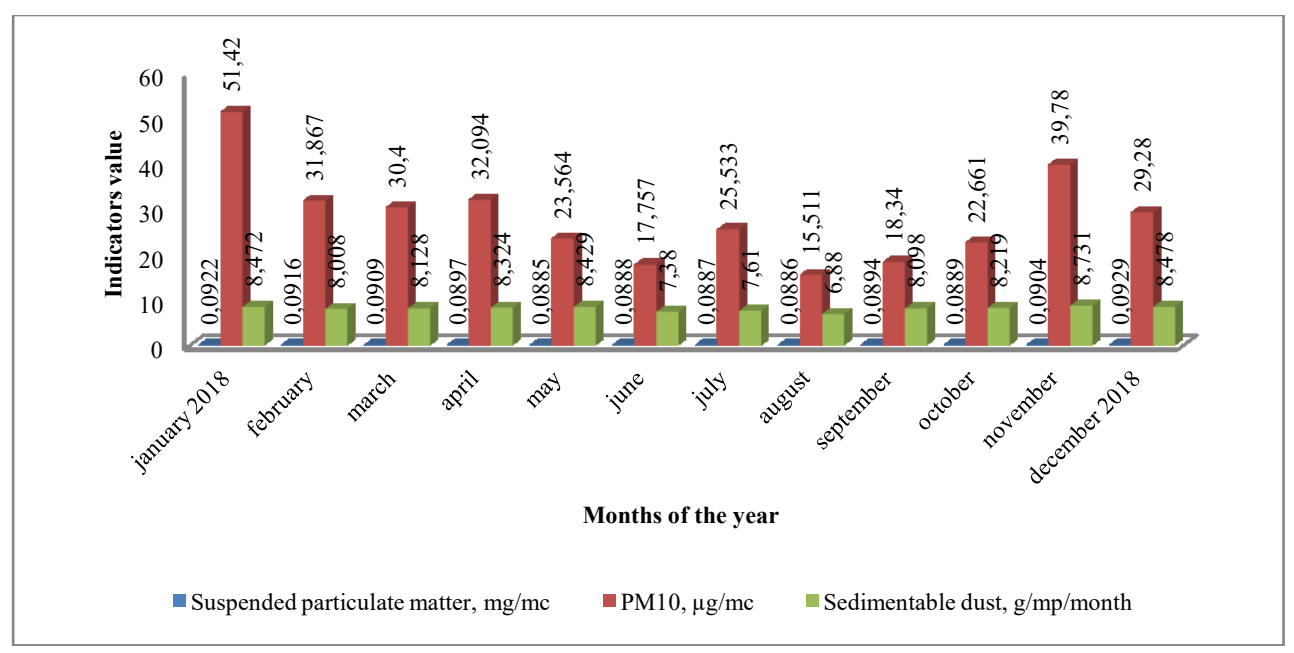

Fig. 3. Monthly averages for suspended particulate matter, PM10 and sedimentable dust during the year 2018 .

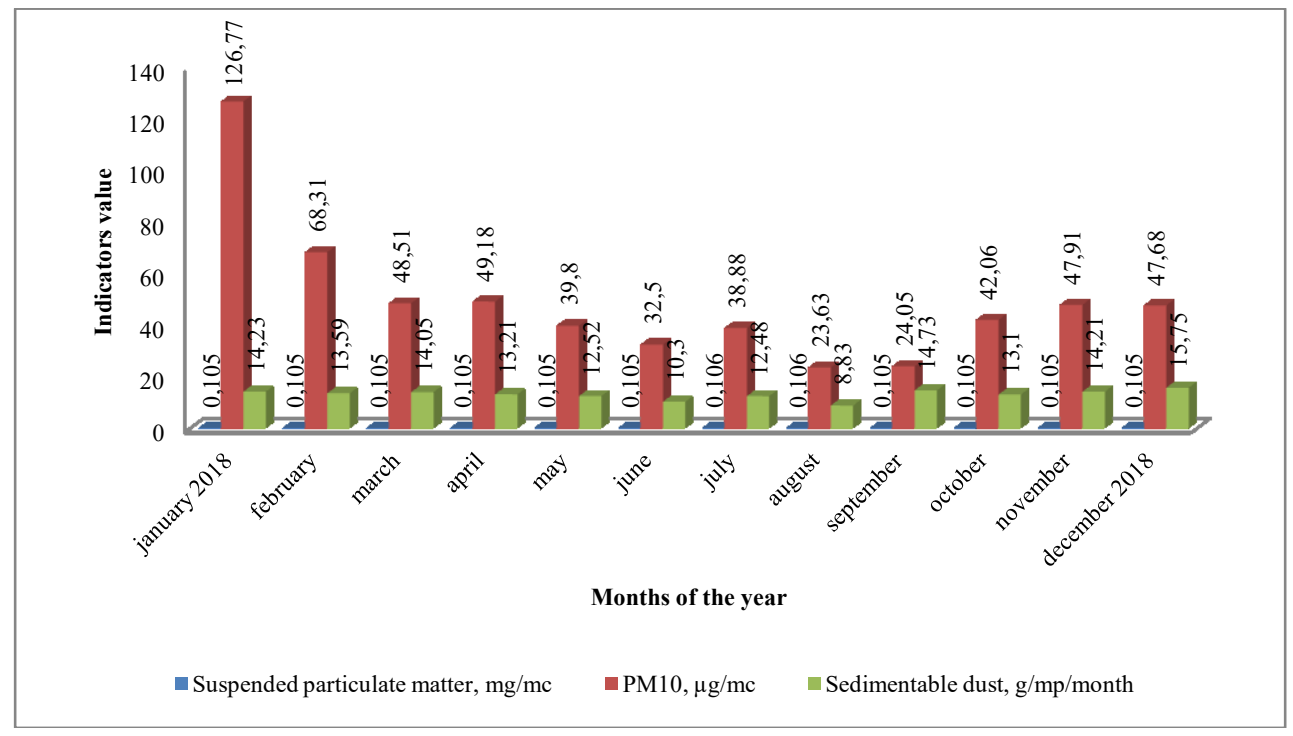

Fig. 4. Monthly maximum values for suspended particulate matter, PM10 and sedimentable dust during the year 2018 . 
Histograms of Figures 3 and 4 shows that the air quality indicators monitored by handheld stations generally fall in the law 104/2011, except for January and February when they exceed limit values. A likely cause of such overruns may be that Paroşeni Thermoelectric Power Plant rehabilitation program is not completed.

Automatic station monitors the air quality indicators: $\mathrm{NO}_{\mathrm{X}} / \mathrm{NO}_{2}, \mathrm{SO}_{2}, \mathrm{CO}, \mathrm{PM} 10$ and $\mathrm{Pb}$. Fuel burning, industrial processes and road traffic are the main potential sources of pollution for these indicators. Figure 5 shows the variation in monthly averages for air quality indicators $\left(\mathrm{SO}_{2}, \mathrm{NO}_{2}, \mathrm{CO}, \mathrm{PM} 10\right)$, and Figure 6 shows the maximum daily average values of the same indicators as a result of measurements made by the automatic station during the year 2018 .



Fig. 5. Monthly averages for $\mathrm{SO}_{2}, \mathrm{NO}_{2}, \mathrm{CO}, \mathrm{PM}_{10}$ during the year 2018 .

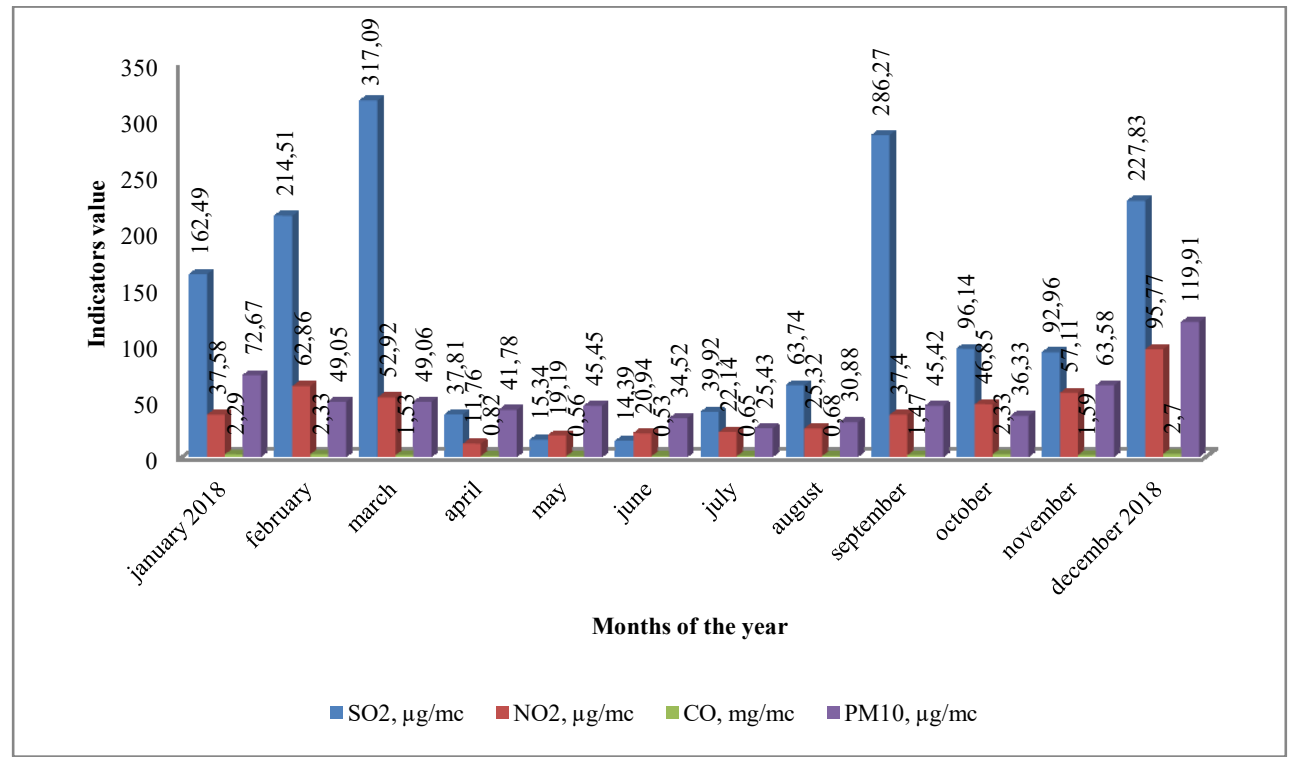

Fig. 6. Maximum daily average values for $\mathrm{SO}_{2}, \mathrm{NO}_{2}, \mathrm{CO}, \mathrm{PM}_{10}$ during the year 2018 . 
Figure 6 shows that the maximum daily average values for the air quality indicators $\left(\mathrm{SO}_{2}, \mathrm{NO}_{2}, \mathrm{CO}, \mathrm{PM} 10\right)$ monitored by the automatic station exceeded the limit values for human health protection during the winter months, a probable cause being that the desulphurization station of Paroșeni Thermoelectric Power Plant has not yet been put into operation.

\section{Transport activity influence on environmental factors}

At present, for human society, transport is an essential activity, but with negative consequences on environmental factors.

According to the LIFE GySTRA project, urban traffic is one of the most important sources of air pollution at European level, with over $60 \%$ of $\mathrm{NO}_{\mathrm{X}}$ emissions being caused by it. Another worrying statistic cited by the project is that $6.5 \%$ of Euro V vehicles are responsible for $35 \%$ of total emissions. [4]. Volume, nature and concentration of pollutants emitted depend on the type of vehicle, the nature of the fuel and the technical conditions of operation. The composition of the exhaust gases is: $\mathrm{CO}$ - carbon monoxide; $\mathrm{CH}_{\mathrm{X}}$ hydrocarbons; $\mathrm{SO}_{2}$ - sulfur dioxide; $\mathrm{NO}_{\mathrm{X}}$ - nitrogen oxides; volatile organic compounds (benzene, $90 \%$ of the amount of benzene in the ambient air comes from road traffic); soot and asbestos $[5,6]$.

Vehicle pollutant emissions have two great features:

- Disposal is very close to the ground, leading to high concentrations at very low heights, even for low density gases and high airborne diffusion capacity;

- Emissions are made over the entire area of the area under consideration, the differences in concentrations depending on the traffic intensity and the possibilities of ventilation of the traffic arteries.

Although it has declined over the past two decades, air pollution is still a major problem in many areas. Increasing freight transport also leads to air quality degradation. Freight transport was one of the main causes of the increase in $\mathrm{NO}_{2}$ concentrations. Industry was fully involved in discussions on Euro 6/VI rules for cars and commercial vehicles. Maximum use should be made of the solutions put on the market by EURO 6/VI by encouraging renewal of the fleet.

From the analysis of the air quality indicators presented above it can be concluded that a significant part of the pollutant emissions in the studied area is given by road traffic with a higher concentration on the main traffic arteries. It is noted that a direct causal relationship between road traffic (increase in the number of motor vehicles) and air quality indicators could not be found.

\section{Conclusions}

Economic development is closely related to the mobility needs of communities, but transport activity has repercussions on the natural environment.

After analyzing data related to air quality, in general it appears that they do not exceed the limit values to protect human health, except for some cold season periods. Traffic study conducted led to the conclusion that significant volumes of traffic recorded in the hours 11.00 to 18.00 pollutant emissions having the highest values. Over $60 \%$ of $\mathrm{NO}_{\mathrm{X}}$ emissions and $40 \%$ of $\mathrm{CO}_{2}$ emissions from road transport are generated by urban traffic. Measures to reduce air pollution need to be considered, especially as the study shows that road traffic will increase significantly in the coming decades.

One of the measures could be the establishment of Petroșani Metropolitan Area, resulting in achieving a clean public transport system and sustainable, given the high degree 
of urbanization of Petroșani Basin. This also involves building infrastructure for the use of electric bicycles and trotters and promoting this travel system.

\section{References}

1. Official Journal of the European Union, C 184 E, 50-56 (2010). Available on https://eur-lex. europa.eu/legal-content/RO/TXT/PDF/?uri=CELEX:52009IP0308\&qid=1564423715551\&from= EN

2. Institutul Naţional de Statistică, Recensământul populaţiei şi al locuinţelor. Available on http:// www.recensamantromania.ro/wp-content/uploads/2012/08/TS6.pdf

3. Agenția pentru Protecția Mediului Hunedoara, Available on http://www.anpm.ro/ro/web/apmhunedoara/

4. LIFE GySTRA. Available on https://www.lifegystra.eu/en/

5. A. A. Boroiu, A. Boroiu, E. Neagu, 8th International Conference on Advanced Concepts in Mechanical Engineering (ACME) 2018 444, 072020 (2018)

6. G. Mitran, S. Ilie, Environmental Engineering and Management Journal, 13 (8), 1945-1956 (2014)

7. C. Dura, I. Drigă, C. Isac, Environmental Engineering and Management Journal, 16 (6), 12691274 (2017)

8. G. Băbuț, R. I. Moraru, C. Dura, Quality - Acces to Success Journal, 16 (146), 103-112 (2015) 